\title{
EFFECT OF DRYING METHOD ON QUALITY OF SOYBEAN SEED
}

\author{
M. R. Ali ${ }^{1}$, M. M. Rahman ${ }^{2}$, M. S. Rahman ${ }^{3}$, M. M. Hossain ${ }^{1}$ and M. Asaduzzaman ${ }^{1}$ \\ ${ }^{1}$ Regional Agricultural Research Station, BARI, Jamalpur, \\ ${ }^{2}$ Professor, Department of Agronomy, BAU, Mymensingh, \\ ${ }^{3}$ Upazila Agriculture Officer, DAE, Gopalpur, Tangail
}

Key words: Soybean, seed moisture, drying condition, viability, germination index

\begin{abstract}
The experiment was conducted at the Seed Laboratory, Regional Agricultural Research Station, BARI, Jamalpur in 2010 with a view to study the effect of drying method on soybean seed germination and seedling vigour. Eight drying condition viz., i) Cemented floor ii) Tripale upon cemented floor iii) Bamboo chatai upon cemented floor, iv) Cloth upon cemented floor, v) Earthen floor, vi) Tripale upon earthen floor, vii) Bamboo chatai upon earthen floor and viii) Cloth upon earthen floor were included in the experimental treatment variables with three replications using a completely randomized design. Seed moisture content (\%), germination (\%), germination index, and seedling dry weight (g) were recorded at 50, 100, 150 and 200 days after storage (DAS). The highest germination percentage, germination index and seedling dry matter was obtained from tripale over cemented floor followed by bamboo chatai over cemented floor, tripale over earthen floor and bamboo chatai over earthen floor. The lowest germination percentage, germination index and seedling dry matter was obtained from cemented floor.
\end{abstract}

\section{Introduction}

Soybean (Glycine max [L.] is the world's most important grain legume crop in terms of total production and international trade. Soybean seed contains $36-47 \%$ protein and $15-25 \%$ oil, 20-26\% carbohydrate (Rahman, 2001). It is rich in Calcium $\left(208 \mathrm{mg} 100^{-1} \mathrm{~g}\right)$, Iron $(11.5 \mathrm{mg}$ $\left.100^{-1} \mathrm{~g}\right)$, Carotene $\left(426.0 \mathrm{~g} 100^{-1} \mathrm{~g}\right)$, phosphorus and thiamine including vitamins $\mathrm{A}, \mathrm{B}, \mathrm{C}$ and $\mathrm{D}$ (Alam and Rahman, 2005). The demand of soybean is increasing for making different food products for human consumption as well as feed for poultry and fish in Bangladesh. Soybean meal is the most important and high valued ingredient for poultry and fish feed as it is the only vegetable protein with a near complete balance of essential amino acids needed in higher animal nutrition (Hari, 2000). Now-a-days the demand of soybean in the feed industry has been increased. The average yield of soybean in Bangladesh is low, only $1.47 \mathrm{t} \mathrm{ha}^{-1}$ (BBS, 2009). The area under the crop has been increased currently to around 40,000 ha which produced about 59,000 t (Krishi Projukti Hatboi, 2014). But the climate and soil of Bangladesh are congenial for soybean production and it can widely be grown across Bangladesh. The farmers of Noakhali and Lakshmipur districts have now become very much interested in soybean cultivation $(39,137$ ha and production $53383 \mathrm{t})$ since the demand of soybean has been increased recently in the domestic market mainly as poultry feed (BBS, 2009). But the shortage of quality seed supply in planting time is a major problem to the production and expansion of soybean. The seed available in the market is often of poor quality in respect of health, germination and vigor. This is because soybean seed loses its viability within a very short time in storage under ambient conditions (Singh et al., 1989, Woodruff, 1998). Manipulation of storage environment could help to improve or maintain seed quality. The present study was 
Ali et al.

therefore, undertaken with a view to find out the effect of different sun drying methods on soybean seed quality.

\section{Materials and Methods}

An experiment was conducted at Seed Laboratory of Regional Agricultural Research Station, Jamalpur during the period from May to December 2010 with a view to study the effect of different sun drying methods on soybean seed quality. Soybean var. Shohag (PB1) collected from Bangladesh Agricultural Research Institute (BARI), Joydebpur, Gazipur was sown at Regional Agricultural Research Station Farm, Jamalpur with proper agronomic management. The crop was harvested at full maturity. After proper processing and cleaning the seed was dried in the sun to about $8 \%$ seed moisture content (SMC) following the condition specified viz., i) Cemented floor ii) Tripale upon cemented floor iii) Bamboo chatai upon cemented floor, iv) Cloth upon cemented floor, v) Earthen floor, vi) Tripale upon earthen floor, vii) Bamboo chatai upon earthen floor and viii) Cloth upon earthen floor. The experiment was arranged in a Completely Randomized Design with three replicates. The seed was tested for different quality parameters at 50,100, 150 and 200 days after storage (DAS). The seeds were kept in the polythene bag $\left(0.05 \mathrm{~mm}\right.$ thickness) under ambient room condition $\left(23-32{ }^{\circ} \mathrm{C}\right)$. The quality parameters tested were seed moisture content, germination percentage, germination index, and seedling dry matter.

Seed moisture content: Moisture content of seed was measured using high constant temperature oven dry method following ISTA rules (ISTA, 2003). About 5-8g of soybean seeds were placed in an aluminum dish and dried in oven at $130 \mathrm{C}$ for 2 hours (until constant weight achieved). After that the samples were cooled in a desecrator and weighed.

Germination percent: Germination test of seed was done in the sand-petridis method using sterilized sand. Randomly collected 50 seeds in three replicates per bag were used in the test. The sand was moistened to $60 \%$ water holding capacity before placing it on the petridish. Seed germination was counted at 8 days after placing the seed. The number of normal seedlings, abnormal seedlings and dead seeds were recorded and germination percentage was counted as per ISTA rules (ISTA, 2003).

Germination index (GI): Germination index of seed was estimated from counting of the number of germinating seed each day up to 8 days of setting the test using the formula given by Association of Official Seed Analysts (Rahman et al., 2010).

$\mathrm{GI}=\frac{\text { No.of seedling at } 1 \text { st count }}{\text { Days to } 1 \text { st count }}+---++\frac{\text { No.of seedling at final count }}{\text { Days to final count }}$

Seedling dry matter: The normal seedlings from each germination lot were collected, washed with running tap water and surface dried. The seedlings were then dried in the oven at $70^{\circ} \mathrm{C}$ for 72 hours (until constant weight reached) and the weight expressed seedling ${ }^{-1}$ basis.

Field emergence: At the end of the storage period (200 DAS), randomly selected 100 seeds from each seed lot in three replications were sown in the well prepared field. The number of seedlings emerged each day were counted up to 15 days after sowing. Data analysis was done statistically and the means were compared by Duncan's Multiple Range Test (Gomez and Gomez, 1984). 
Effect of Drying Method on Quality of Soybean Seed

\section{Seed moisture content}

\section{Results and Discussion}

The effect of drying condition on moisture content of soybean seed at each of the observation dates during the storage period was statistically significant. It was found that the seed moisture content increased with the increases of storage period. The moisture content was higher for the cemented floor drying method than other drying method. The seed moisture content for cemented floor were 8.55, 9.10, 9.59 and 10.31\%, respectively at 50, 100, 150 and 200 days after storage. Those values on tripale over cemented floor were 8.05, 8.40, 8.62 and $9.02 \%$, respectively and it was statistically lowest compared to other drying condition (Table1). Similar result was observed by Nautiyal and Joshi, 1991.

Table 1. Effect of drying condition on moisture content of soybean seed at different days after storage in 2010

\begin{tabular}{l|ccc|c}
\hline \multirow{2}{*}{ Drying condition } & \multicolumn{4}{|c}{ Seed moisture content (\%) } \\
\cline { 2 - 5 } & 50 DAS & 100 DAS & 150 DAS & 200 DAS \\
\hline Cemented floor & $8.55 \mathrm{a}$ & $9.1 \mathrm{a}$ & $9.59 \mathrm{a}$ & $10.31 \mathrm{a}$ \\
Tripale over cemented floor & $8.05 \mathrm{c}$ & $8.4 \mathrm{c}$ & $8.62 \mathrm{~b}$ & $9.02 \mathrm{~b}$ \\
Bamboo chatai over cemented floor & $8.15 \mathrm{~b}$ & $8.84 \mathrm{~b}$ & $9.45 \mathrm{a}$ & $10.14 \mathrm{a}$ \\
Cloth over cemented floor & $8.15 \mathrm{~b}$ & $8.93 \mathrm{ab}$ & $9.56 \mathrm{a}$ & $10.13 \mathrm{a}$ \\
Earthen floor & $8.25 \mathrm{~b}$ & $8.82 \mathrm{~b}$ & $9.35 \mathrm{a}$ & $10.22 \mathrm{a}$ \\
Tripale over earthen floor & $8.25 \mathrm{~b}$ & $8.93 \mathrm{ab}$ & $9.54 \mathrm{a}$ & $10.28 \mathrm{a}$ \\
Bamboo chatai over earthen floor & $8.11 \mathrm{c}$ & $8.83 \mathrm{~b}$ & $9.46 \mathrm{a}$ & $10.21 \mathrm{a}$ \\
Cloth over earthen floor & $8.30 \mathrm{ab}$ & $9.00 \mathrm{ab}$ & $9.42 \mathrm{a}$ & $10.19 \mathrm{a}$ \\
\hline CV (\%) & 4.17 & 7.33 & 6.47 & 5.26 \\
\hline
\end{tabular}

DAS= Days after storing, $\mathrm{CV}=$ Coefficient of variance,

In a column, figures having similar letter(s) do not differ significantly

\section{Germination percentage}

The effect of drying condition on germination percentage of soybean seed was statistically significant at each of the observation dates during storage period. It was found that the germination percentage decreased with the length of storage period. The decrease was higher for cemented floor drying condition than other drying condition. The present study revealed that seeds dried on tripale over a cemented floor showed the highest germination performance while those seeds dried on cemented floor showed the lowest germination percentage. The germination percentage on tripale over cemented floor were 94.0, 90.0, 88.0 and 86.0\%, respectively at 50,100, 150 and 200 DAS and it was statistically similar with other drying method except cemented floor, on cloth over cemented floor and earthen floor drying condition while those values for cemented floor were 80.0, 74.0, 68.0 and 60.0\%, respectively (Table 2). This result is in agreement with the findings of Bhatt (2004) who reported that soybean seed should not be spread on the cemented floor directly as the heat generated from the surface reduces the viability of the seed.

\section{Field emergence}

The effect of drying condition on field emergence of soybean seed was statistically significant. The field emergence was evaluated at 200 DAS. The highest field emergence (84\%) was obtained on tripale over cemented floor and it was statistically similar to drying on bamboo chatai over cemented floor, tripale over earthen floor and bamboo chatai over earthen floor, respectively. The lowest germination (56\%) was recorded from cemented floor drying condition (Table 2). 
Ali et al.

Table 2. Effect of drying condition on germination of soybean seed at different days after storage in 2010

\begin{tabular}{l|c|c|c|c|c}
\hline Drying condition & \multicolumn{4}{|c|}{ Germination (\%) } & Field emergence \\
& $50 \mathrm{DAS}$ & $100 \mathrm{DAS}$ & $150 \mathrm{DAS}$ & $200 \mathrm{DAS}$ & at 200 DAS \\
\hline Cemented floor & $80 \mathrm{c}$ & $74 \mathrm{c}$ & $68 \mathrm{c}$ & $60 \mathrm{~d}$ & $56 \mathrm{~d}$ \\
& $(61.30)$ & $(57.29)$ & $(53.71)$ & $48.99)$ & $(46.75)$ \\
Tripale over cemented floor & $94 \mathrm{a}$ & $90 \mathrm{a}$ & $88 \mathrm{a}$ & $86 \mathrm{a}$ & $84 \mathrm{a}$ \\
& $(73.72)$ & $(69.41)$ & $(67.44)$ & $(65.93)$ & $(64.18)$ \\
Bamboo chatai over cemented & $92 \mathrm{ab}$ & $90 \mathrm{a}$ & $86 \mathrm{a}$ & $84 \mathrm{ab}$ & $82 \mathrm{ab}$ \\
floor & $(71.05)$ & $(69.27)$ & $(65.93)$ & $(64.18)$ & $(62.62)$ \\
Cloth over cemented floor & $90 \mathrm{ab}$ & $85 \mathrm{~b}$ & $80 \mathrm{~b}$ & $74 \mathrm{c}$ & $70 \mathrm{c}$ \\
& $(69.27)$ & $(65.02)$ & $(61.21)$ & $(57.29)$ & $(54.83)$ \\
Earthen floor & $88 \mathrm{~b}$ & $84 \mathrm{~b}$ & $80 \mathrm{~b}$ & $78 \mathrm{bc}$ & $76 \mathrm{bc}$ \\
& $(68.05)$ & $(64.18)$ & $(61.26)$ & $(60.08)$ & $(58.63)$ \\
Tripale over earthen floor & $92 \mathrm{ab}$ & $90 \mathrm{a}$ & $86 \mathrm{a}$ & $82 \mathrm{ab}$ & $80 \mathrm{ab}$ \\
& $(71.86)$ & $(69.09)$ & $(66.65)$ & $(62.62)$ & $(61.67)$ \\
Bamboo chatai over earthen & $92 \mathrm{ab}$ & $90 \mathrm{a}$ & $84 \mathrm{ab}$ & $80 \mathrm{bc}$ & $78 \mathrm{ab}$ \\
floor & $(71.31)$ & $(69.16)$ & $(64.18)$ & $(61.21)$ & $(59.89)$ \\
Cloth over earthen floor & $90 \mathrm{ab}$ & $88 \mathrm{a}$ & $84 \mathrm{ab}$ & $80 \mathrm{bc}$ & $76 \mathrm{bc}$ \\
& $(69.60)$ & $(67.44)$ & $(64.18)$ & $(61.21)$ & $(58.63)$ \\
\hline CV (\%) & 2.54 & 1.37 & 2.33 & 2.64 & 2.82 \\
\hline
\end{tabular}

DAS= Days after storing, $\mathrm{CV}=$ Coefficient of variance,

a Figures in parenthesis indicates the Arc Sine transformed value, In a column, figures having similar letter(s) do not differ significantly

\section{Germination index}

The effect of drying condition on germination index was statistically significant at each of the observation dates during the storage period in 2010. It was found that the germination index decreased with the length of storage period. The decrease was higher for cemented floor drying condition than other drying condition. The germination index of soybean seed drying on tripale over cemented floor were 28.84, 26.60, 24.65 and 21.76, respectively at 50, 100, 150 and 200 DAS and these values were the highest and statistically similar to other drying method except cemented floor, cloth over cemented floor and earthen floor drying condition while those values for cemented floor were 22.73, 20.80, 16.63 and 13.48, respectively (Table 3).

Table 3. Effect of drying condition on germination index of soybean seed at different DAS in 2010

\begin{tabular}{l|c|c|c|c}
\hline \multirow{2}{*}{ Drying method } & \multicolumn{4}{|c}{ Germination index } \\
\cline { 2 - 5 } & 50 DAS & 100 DAS & 150 DAS & 200 DAS \\
\hline Cemented floor & $22.73 \mathrm{~b}$ & $20.80 \mathrm{c}$ & $16.63 \mathrm{c}$ & $13.48 \mathrm{c}$ \\
Tripale over cemented floor & $28.84 \mathrm{a}$ & $26.60 \mathrm{a}$ & $24.65 \mathrm{a}$ & $21.76 \mathrm{a}$ \\
Bamboo chatai over cemented floor & $28.41 \mathrm{a}$ & $26.27 \mathrm{a}$ & $24.41 \mathrm{a}$ & $21.10 \mathrm{a}$ \\
Cloth over cemented floor & $23.59 \mathrm{~b}$ & $21.06 \mathrm{c}$ & $19.26 \mathrm{bc}$ & $17.50 \mathrm{~b}$ \\
Earthen floor & $24.14 \mathrm{~b}$ & $22.68 \mathrm{bc}$ & $20.95 \mathrm{ab}$ & $18.05 \mathrm{~b}$ \\
Tripale over earthen floor & $28.37 \mathrm{a}$ & $26.74 \mathrm{a}$ & $24.01 \mathrm{a}$ & $21.43 \mathrm{a}$ \\
Bamboo chatai over earthen floor & $27.04 \mathrm{a}$ & $25.14 \mathrm{ab}$ & $24.02 \mathrm{a}$ & $21.50 \mathrm{a}$ \\
Cloth over earthen floor & $26.15 \mathrm{a}$ & $24.81 \mathrm{ab}$ & $22.03 \mathrm{ab}$ & $19.71 \mathrm{ab}$ \\
\hline CV $(\%)$ & 9.71 & 4.51 & 6.27 & 6.70 \\
\hline
\end{tabular}

DAS = Days after storing, $\mathrm{CV}=$ Coefficient of variance,

In a column, figures having similar letter(s) do not differ significantly 
Effect of Drying Method on Quality of Soybean Seed

\section{Seedling dry matter}

The effect of drying condition on seedling dry matter of soybean seedling was statistically significant at each of the observation dates during the storage period in 2010. It was found that the seedling dry matter decreased with the length of storage period. The decrease was higher for cemented floor drying condition than other drying conditions. The seedling dry matter of soybean drying on tripale over cemented floor were $0.118,0.116,0.115$ and $0.114 \mathrm{~g}$ seedling ${ }^{-1}$, respectively at 50,100,150 and 200 DAS and it was statistically similar to other drying conditions except cemented floor, cloth over cemented floor, earthen floor, bamboo chatai over earthen floor and cloth over earthen floor drying condition while those values for cemented floor were 0.092, 0.090, 0.080 and $0.070 \mathrm{~g}$ seedling ${ }^{-1}$, respectively (Table 4).

Table 4. Effect of drying condition on dry matter of soybean seedling at different days after storage in 2010

\begin{tabular}{l|c|c|c|c}
\hline \multirow{2}{*}{ Drying condition } & \multicolumn{4}{|c}{ Seedling dry matter (g seedling ${ }^{-1}$ ) } \\
\cline { 2 - 5 } & 50 DAS & 100 DAS & 150 DAS & 200 DAS \\
\hline Cemented floor & $0.092 \mathrm{c}$ & $0.090 \mathrm{c}$ & $0.08 \mathrm{c}$ & $0.070 \mathrm{c}$ \\
Tripale over cemented floor & $0.118 \mathrm{a}$ & $0.116 \mathrm{a}$ & $0.115 \mathrm{a}$ & $0.114 \mathrm{a}$ \\
Bamboo chatai over cemented floor & $0.116 \mathrm{a}$ & $0.115 \mathrm{a}$ & $0.113 \mathrm{a}$ & $0.112 \mathrm{a}$ \\
Cloth over cemented floor & $0.105 \mathrm{~b}$ & $0.102 \mathrm{~b}$ & $0.095 \mathrm{~b}$ & $0.096 \mathrm{~b}$ \\
Earthen floor & $0.096 \mathrm{c}$ & $0.095 \mathrm{c}$ & $0.092 \mathrm{~b}$ & $0.092 \mathrm{~b}$ \\
Tripale over earthen floor & $0.116 \mathrm{a}$ & $0.114 \mathrm{a}$ & $0.111 \mathrm{a}$ & $0.109 \mathrm{a}$ \\
Bamboo chatai over earthen floor & $0.101 \mathrm{~b}$ & $0.100 \mathrm{~b}$ & $0.099 \mathrm{~b}$ & $0.097 \mathrm{~b}$ \\
Cloth over earthen floor & $0.103 \mathrm{~b}$ & $0.101 \mathrm{~b}$ & $0.096 \mathrm{~b}$ & $0.093 \mathrm{~b}$ \\
\hline CV (\%) & 6.99 & 6.38 & 8.49 & 7.66 \\
\hline
\end{tabular}

DAS= Days after storing, $\mathrm{CV}=$ Coefficient of variance,

In a column, figures having similar letter(s) do not differ significantly

\section{Conclusion}

The study concludes that soybean seeds could be sun dried on tripale upon a cemented floor to $8 \%$ SMC (Seed moisture content) for storing to maintain high seed quality.

\section{References}

Gomez, K. A. and A.A. Gomez. 1984. Statistical procedures for Agricultural Research $2^{\text {nd }}$ Edn. John Willy and Sons., New York. pp. 97-111.

Hari B. K. 2004. Biochemistry and molecular biology of soybean seed storage protein. J. New Seeds. 2(3): 342-350.

Hossain M. 2007. Effect of field environment on growth, seed yield and quality of soybean. Ph. D Thesis. Dept. Agron. Bangladesh Agril Univ., Mymensingh. pp. 108-115.

ISTA, 2003. International Rules for Seed Testing, 2003. Zurich, Switzerland, ISTA.

Krishi Projukti Hatboi. 2014. Krishi Projukti Hatboi Khondo-1 (6th edition). Bangladesh Agricultural Research Institute (BARI), Joydebpur, Gazipur p. 264.

Nautiyal, P.C. and Y. C. Joshi. 1991. Storage of rabi/summer groundnut (Arachis hypogea L.) with calcium cloride for prolonged seed viability and vigour. Trop. Sci., 31: 21-26.

Singh, S. R., K. O. Rachie and K. E. Dashiell. 1989. Groundnut for Tropics: Research, Production and Utilization. Jhon Wiley and Sons. Chichester, England. pp. 122-129. 